\title{
How to Develop Comic as an Interesting Media in Teaching Indonesian to Speakers of Other Language (TISOL)?
}

\author{
Devi Nur Farida \\ Universitas Negeri Surabaya \\ Surabaya, Indonesia \\ devi.farida1611@gmail.com
}

\author{
Prima Vidya Asteria \\ Universitas Negeri Surabaya \\ Surabaya, Indonesia \\ primaasteria@unesa.ac.id
}

\begin{abstract}
The TISOL in Indonesia is growing rapidly. This was marked by the presence of TISOL classes at several universities and course institutions. However, the limited learning media used resulted in minimal vocabulary owned by TISOL students. In this case, researchers developed comics as an interesting medium in TISOL. The purpose of this study is to describe the process of development and validity of comics in TISOL to achieve the effectiveness of teaching and learning . The research method used is the $R \& D$ method (Research and Development) according to Borg and Gall . The subjects of this research were BIPA Unesa students at $A 2$ level, amounting to four people. The object of this research is comic. This research instrument is material and graphic validation, field notes, and documentation . The development of education as an alternative interesting learning media with an interesting concept reaches the effectiveness of teaching and learning in TISOL .
\end{abstract}

Keywords - Development, Comics, Effective, TISOL

\section{INTRODUCTION}

The TISOL has a very rapid development in the international world. TISOL is a program aimed at foreign speakers in learning Indonesian. Even more than 72 countries have learned Indonesian. Many foreigners flocked to Indonesia to learn Indonesian. Since 2000, the Language Center, Ministry of National Education, the Republic of Indonesia has been teaching Indonesian language to foreign speakers. In Indonesia, there are many who open TISOL classes, namely in TISOL learning courses, in universities, in language centers, and many more.

One of the universities that open classes for TISOL in Indonesia is Unesa. There are two classes with different levels, namely level A2 and level C2. Level A2 is the most basic level, while $\mathrm{C} 2$ is the advanced level. In teaching and learning activities in TISOL, a problem was found, namely the lack of vocabulary that BIPA students have, especially on A2 level which is the most basic level and requires extra teaching with competent teachers. It is in because kan lack of interest in learning media TISOL. There the learning model is still monotonous which results in a lack of effectiveness in teaching and learning in the classroom. Learning TISOL still uses markers, whiteboards, projector screens and LCDs.
Accordingly, $\mathrm{p}$ enelit $\mathrm{i}$ tried to try to develop an interesting learning media for students TISOL.

Comics is one of learning media selected by the investigator to be developed in TISOL in order to creating effectiveness in teaching and learning activities. Comics are picture story that is easily understood by the reader because it can foster reader imajination, so the researchers had to create the images and text are easy to understand students TISOL. From the nature of things, researchers are trying to develop a comic with the concept and compelling content to students TISOL corresponding syllabus.

\section{METHODS}

The method used is the $\mathrm{R} \& \mathrm{D}$ method (Research adnd Development) which was adapted from Borg and Gall. The subjects in this study were TISOL Unesa A2 level students totaling four people. The object of this research is comic learning media. This research instrument in the form of material validation and graphics from validators who are experts in their respective fields, field notes, and documentation. This $\mathrm{R} \& \mathrm{D}$ method from Borg and Gall is a method used to develop educational products. In this case, the purpose of this study is to develop comic products for TISOL students. This method has the following ten stages [2]:

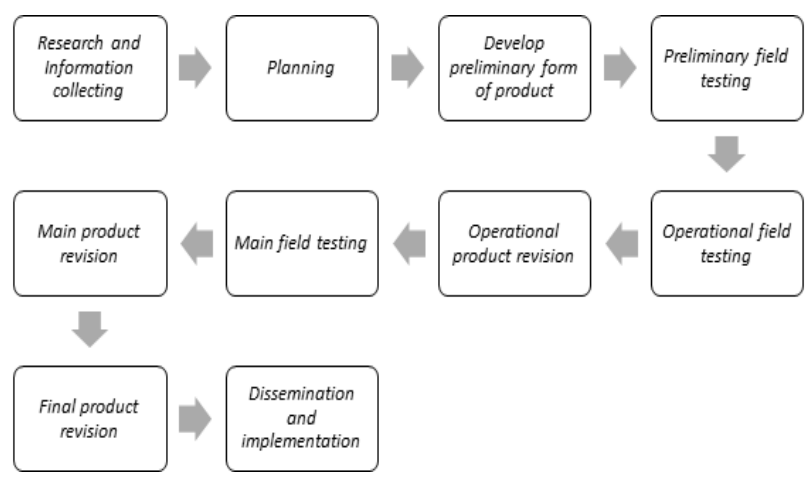

Gb. Borg and Gall R\&D Development Flow Chart 


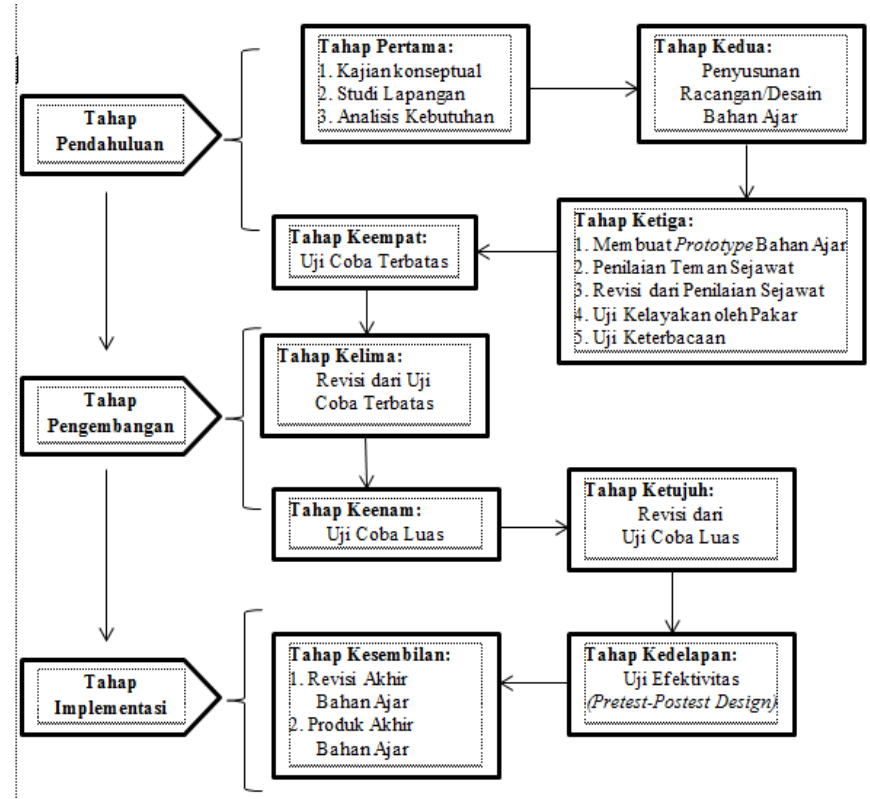

GB Adaptation R \& D Stages from Borg and Gall

\section{RESULTS AND DISCUSSION}

\section{Comic Development Process as Attractive Media in} TISOL

\section{A. Introductory Stage}

\section{First Stage :}

In this introductory stage, there are four stages:

1. Conceptual Study

In this study, researchers studied the concept of comics from various sources to reach comics with interesting models and content to be developed as learning media for TISOL students.

2. Field Study

In this study, the researchers conducted a direct check into the field, namely in TISOL Unesa. Researchers observed their learning process in a class that was still very monotonous. The media used during learning is limited to whiteboards, markers, LCD projectors, and dictionaries. They rarely use learning media because the media is very limited. Researchers will try to make comics as learning media that are interesting to them because it turns out that before they had never used comics in learning.

3. Needs Analysis

In this needs analysis, TISOL students need interesting learning media in the classroom to create learning effectiveness. Based on this, the researcher tried to conceptualize the comic with a pocket model and content in accordance with the syllabus, which is to know the natural environment around Indonesia, treasury ko sakata, and sentence making. The comic media were analyzed to be able to create effectiveness because the concept of comics in the form of illustrated stories made it easy for TISOL students to understand the contents based on images and text.

\section{Second Stage}

At this stage, the researcher will arrange the design/design of teaching materials. Researchers design comic scripts with the theme of the natural environment. The natural environment that is incorporated into comic content is in the form of rivers, forests, beaches and rice fields . Because the concept of comics is in the form of a pocket, so only a few natural environments are included. The four natural environments are very easy to find in the Indonesian region, making it easier for TISOL students to know and understand comic content. There is another uniqueness of this comic concept, namely on the last page there is a quiz page to review the material that has been read on the previous page. Next, researchers designed illustrations and comic arrangement. Illustrations made in the form of main characters, rivers, forests, beaches, rice fields, and backgrounds that add to the attraction placed in the contents. Color games are used in the form of bright colors, such as, blue, orange, yellow, and green. In this case, the specifications and arrangements made for Mikuta are as follows:

1) There are front cover pages, title pages, character recognition pages, content pages, quiz pages, thank you pages, and back cover pages.

a) The front cover page consists of: title; pictures of rivers, beaches, forests and rice fields; drafting team.

b) The title page contains the comic title.

c) The character recognition page contains pictures of Tono and Sarah.

d) The content page consists of pictures and dialogues about rivers, beaches, forests and rice fields.

e) The quiz page consists of quizzes about vocabulary found on content pages (rivers, beaches, forests, and rice fields).

f) The thank you page contains a thank you note.

g) The back cover page consists of: title, synopsis, picture of the natural environment, drafting team, bar code.

2) The basic colors of comic pages are blue, orange, yellow, and green.

3) Ace Animation Font, size 8pt.

4) Paper size using A6.

5) Paper uses Art Paper (cover and contents). 


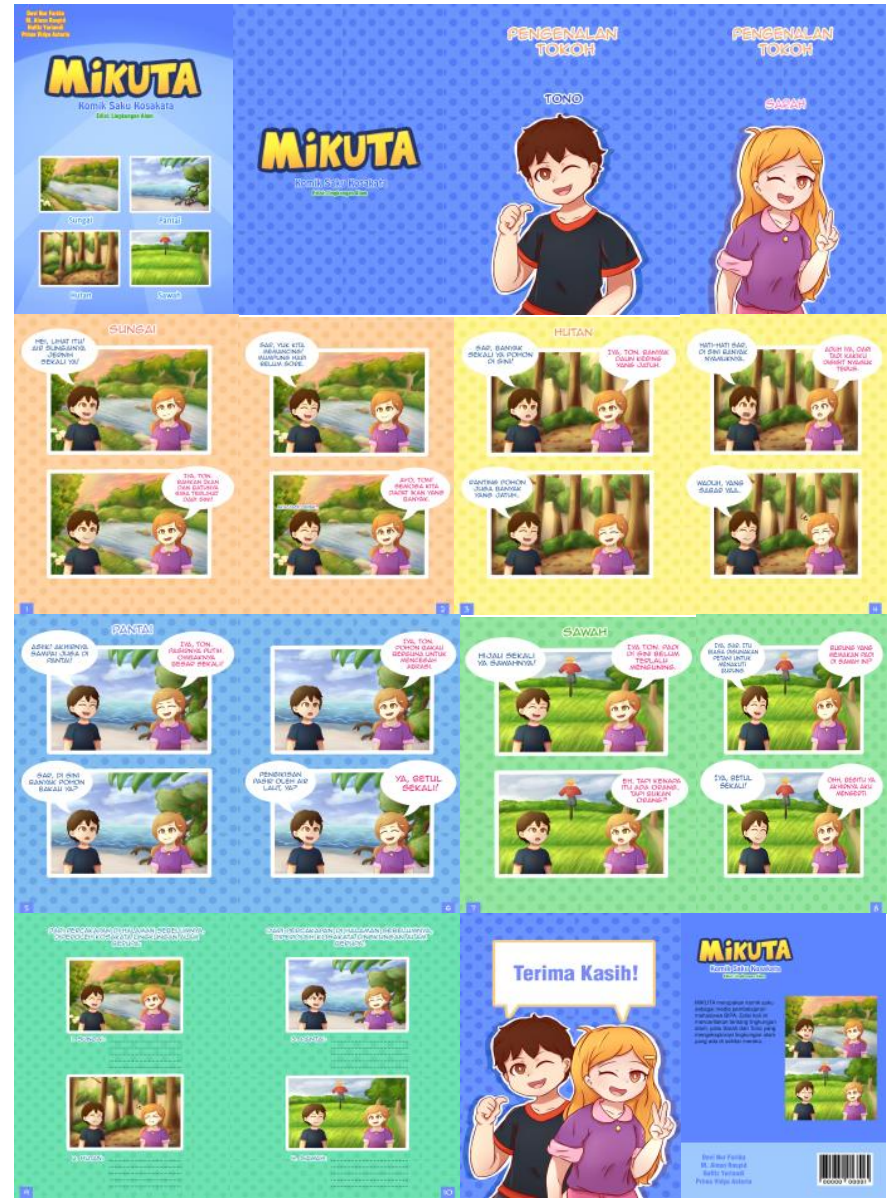

Gb. Comic Design

\section{Third phase}

In this third stage, there are several steps that must be done, namely:

1. Making Prototype of Teaching Materials

The prototype of comic teaching materials for TISOL students is as follows:

2. Validator Assessment

In this assessment, the researcher gave the comic validation instrument directly to the validator who was an expert in the BIPA field and design. The validation is in the form of material/content and graphics. Material validation will be validated by BIPA Unesa lecturer, namely Mrs. Shendy R. Mega, while the graphic validation will be validated by Unesa's art and design instructors, Mr. Hendro.

3. Revision of Validator Assessment

After an assessment by two validators from Unesa according to their fields, there were several revisions of material/content whose vocabulary was not in accordance with the KBBI, namely the word "asiik" should be "fun". In addition there are sentences that can confuse the reader, namely the sentence "Eh, that's why there are people, but not people?" Should be "Eh, but why are there people there?" In addition to material / content, graphics also received a revision of the cover arrangement that was less attractive.

\section{Fourth Stage}

At this stage, the researcher conducted a limited trial or referred to as a learning product simulation. In this simulation, researchers expect input from TISOL students. Researchers introduce and direct the use of the comics tested. After that, researchers asked for input from TISOL students.

\section{B. Development Phase}

At this stage of the clearing, there are three stages which are a continuation of the preliminary stage:

\section{Fifth Stage}

At this stage, the researcher revised the input from students regarding the size of the writing that was less clear. Researchers improve the size of comic writing so that writing can be read clearly.

\section{Sixth Stage}

At this stage, comic products after the revision were tried out to TISOL students in the class. In this case, the BIPA instructor collaborates with researchers to implement the comic product development with several steps of learning. Starting from the opening (greetings, presence, presentation of material, and comic deepening), application (vocabulary search and sentence making), closing ( review of material, greetings).

\section{Seventh Stage}

At this stage, no revisions were made after extensive trials because there were no inputs or revisions during the implementation of comic development in the classroom.

\section{Implementation Phase}

the implementation stage there are two stages which are the continuation of the development stage:

\section{Eighth Stage}

At this stage, researchers conducted an assessment of the vocabulary found and sentences made as a form of product effectiveness. The vocabulary obtained in one comic is about forty and sentences can be made around 30 . The students not only look at the text, but also in the picture.

\section{Ninth Stage}

At this stage, the researchers agreed to develop the pocket comic product into an interesting learning media in TISOL. The following is a comic picture after going through several revisions and is the final product of teaching materials in this study: 


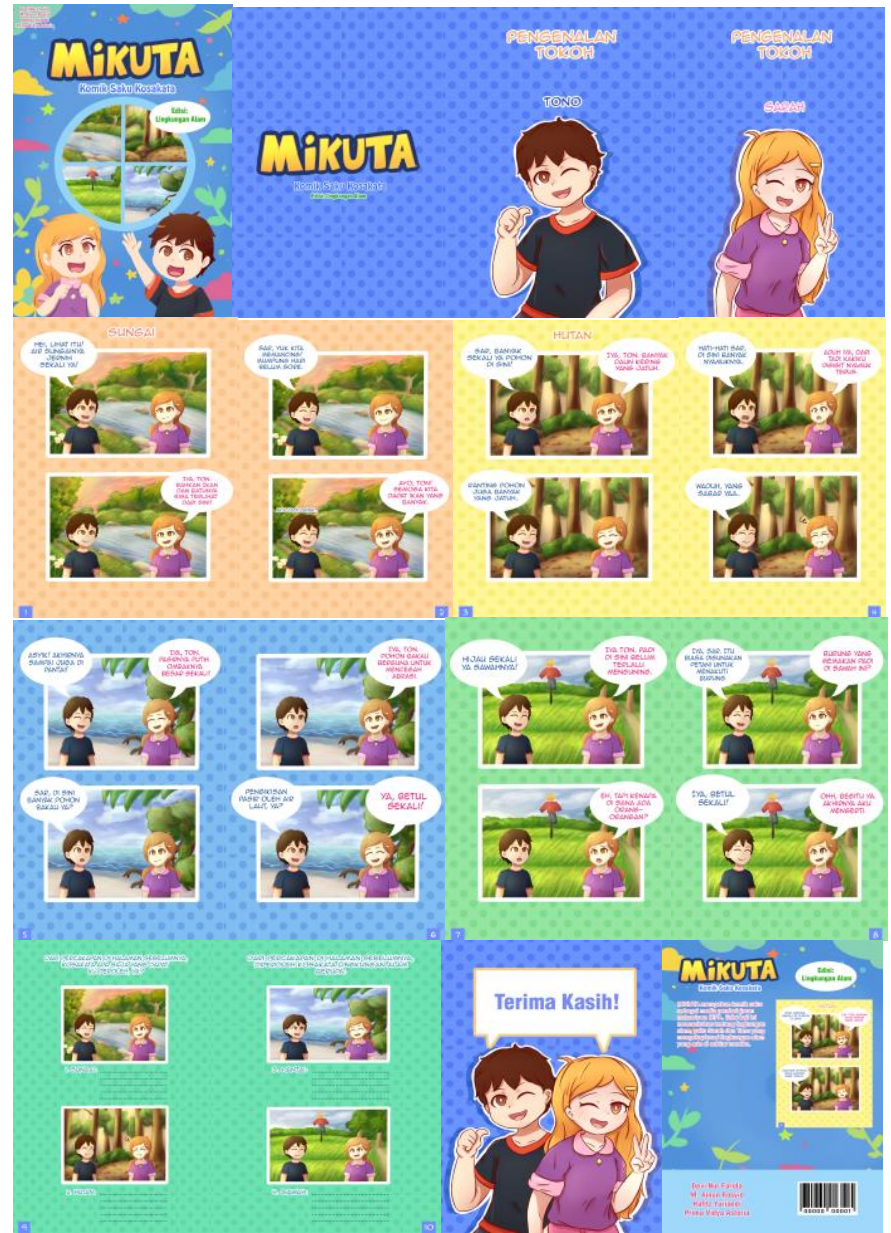

Gb. Comic Design After Revision

\section{CONCLUSION}

Teaching and learning activities in the classroom can affect students' learning progress. It becomes very important to get an attention about the learning media used. Learning media can help the smooth running of teaching and learning activities. In this study, researchers tried to develop comics as an interesting learning media in TISOL. In TISOL has limited learning media so that the vocabulary they have is still minimal. Comics can help in TISOL teaching and learning activities through pictorial stories that make it easier for them to understand the content in comics. Comic design is very simple with the concept of pocket shapes and natural environment material (rivers, forests, beaches, and rice fields) through several stages of $\mathrm{R} \& \mathrm{D}$ development adapted from Borg and Gall, so that development can achieve validity that can create effectiveness in the classroom.

\section{REFERENCES}

[1] R. Asyhar, Kreatif Mengembangkan Media Pembelajaran. Jakarta: Referensi Jakarta, 2012.

[2] W.R. Borg and M.D. Gall, Educational Research: An Introduction, Fifth Edition. New York: Longman, 1989.

[3] R.W. Danaswari, Pengembangan Bahan Ajar dalam Bentuk Media Komik untuk Meningkatkan Hasil Belajar Siswa Kelas X SMAN 9 Cirebon. Skripsi. IAIN Syekh Nurjati, Cirebon: Fakutas Tarbiyah, 2012.

[4] D.D. Fauziyyah, Pengembangan Multimedia Interaktif Berbasis Kecerdasan Jamak dalam Pembelajaran Inkuiri untuk Meningkatkan Kemampuan Menulis Cerita Pendek di SMA Daarul Quran Bandung. UPI: Perpustakaan, 2013.

[5] D. Hayuwari, Deashara, Skripsi: Pengembangan Media Pembelajaran Komik Foto untuk Meningkatkan Motivasi Belajar Siswa Kelas XI Program Studi Akuntansi SMK Negeri 1 Godean Tahun Ajaran 2015/2016. UNY: FE, 2016.

[6] D. Kusmiatun, Mengenal BIPA dan Pembelajarannya. Yogyakarta: K Media, 2016.

[7] Lubis and Hasanah. Artikel: Penggunaan MediaKomik Melalui Metode Learning Starts With A Question dalam Meningkatkan Hasil Belajar Siswa. Sumatera Utara: FE Universitas Muhammadiyah Sumatera Utara, 2016.

[8] S. Nana and R. Ahmad, Media Pengajaran. Bandung: PT Sinar Baru Algesindo, 2012.

[9] S. Nunuk Suryani and A. Leo, Strategi Belajar Mengajar. Yogyakarta: Penerbit Ombak, 2012.

[10] Pratiwi and Kurniawan, Penerapan Media Komik sebagai Media Pembelajaran Ekonomi di SMA Negeri 3 Ponorogo. Surabaya: FE Unesa, 2016.

[11] R. Ramliyana, Media Komik Sebagai Upaya Peningkatan Penguasaan Kosakata Dalam Pembelajaran Bahasa Indonesia bagi Penutur Asing (BIPA). Riksa Bahasa. Volume 2, no.2, 2016

[12] Sadiman, Media Pendidikan Pengertian, Pengembangan, dan Pemanfaatannya. Jakarta : PT Raja Grafindo Persada, 2011.

[13] R. Susilana, and R. Cepi Media Pembelajaran: Hakikat, Pengembangan, Pemanfaatan, dan Penilaian. Bandung : CV Wacana Prima, 2007. 